\title{
Trophic parameters and method validation in Lake Riñihue (North Patagonia: Chile) from 1978 through 1997
}

\author{
Parámetros tróficos y validación de métodos en el Lago Riñihue \\ (Patagonia norte: Chile) durante 1978-1997 \\ STEFAN WOELFL ${ }^{1, *}$, LORENA VILLALOBOS ${ }^{1} \&$ ÓSCAR PARRA ${ }^{2}$ \\ ${ }^{1}$ Instituto de Zoología, Universidad Austral de Chile, Casilla 567, Valdivia, Chile; \\ e-mail: swoelfl@uach.cl \\ ${ }^{2}$ Centro EULA, Universidad de Concepción, Chile
}

\begin{abstract}
Lake Riñihue is the last in a chain of glacially derived oligotrophic lakes in southern Chile and was the subject of limnological research by Dr. Hugo Campos and co-workers at the Universidad Austral de Chile, Valdivia, Chile, since the 1970's. Prof. Campos died in the field in 1998, and this paper now presents a review of these data with comments on methodology relevant to trophic parameters of this lake. Data are presented on inorganic nutrients, chlorophyll $a$, phytoplankton biomass, primary production and Secchi depth obtained over a period of 21 years between 1978 and 1997 in order to evaluate potential changes in these parameters over time. Non-parametric Wilcoxon rank sum tests were applied to determine temporal trends and revealed: (1) total phosphorus showed a significant increase (TP: $2.7 \mathrm{mg} \mathrm{P} \mathrm{L}^{-1}$ to $6.5 \mathrm{mg} \mathrm{P} \mathrm{L}^{-1}$ ), (2) Secchi depth, soluble reactive phosphorus and primary production did not change significantly, (3) chlorophyll $a$ changed significantly among different years, but did not reveal a clear temporal trend, (4) nitrate showed an upward trend and increased concentrations during the early 1990 period, although this data remain in doubt due to methodological anomalies, and (5) the phytoplankton biomass showed significantly higher values during the 1980 period. The significant increase in total phosphorus may reflect increasing usage of grassland within the catchment area. A number of anomalies discovered in historical data sets related to methodology are analysed and discussed within the context of the study.
\end{abstract}

Key words: eutrophication, north Patagonian lake, nutrients, trophy, analytical methods.

\section{RESUMEN}

El lago Riñihue es el último en una cadena de lagos oligotróficos, de origen glacial, en del sur Chile, y fue sujeto de investigaciones limnológicas por el Dr. Hugo Campos y colaboradores de la Universidad Austral de Chile, Valdivia, Chile, desde 1970. El Profesor Campos falleció en terreno en 1998 y esta publicación ahora presenta una revisión de estos datos con comentarios acerca de la metodología concerniente a parámetros tróficos de este lago. Se presentan datos de nutrientes inorgánicos, clorofila $a$, fitobiomasa, productividad primaria y profundidad de Secchi obtenidos a través de un período de 21 años entre 1978 y 1997, con el objetivo de evaluar cambios potenciales de estos parámetros a través del tiempo. Se utilizaron pruebas no paramétricas de Wilcoxon para determinar tendencias temporales y ellas revelaron que: (1) el fósforo total mostró un aumento significativo (TP: $2,7 \mathrm{mg} \mathrm{P} \mathrm{L}^{-1}$ a $6,5 \mathrm{mg} \mathrm{P} \mathrm{L}^{-1}$ ), (2) la profundidad de Secchi, el fósforo reactivo soluble y la productividad primaria no cambiaron significativamente, (3) la clorofila a cambió significativamente entre diferentes años, pero no revela una clara tendencia temporal, (4) el nitrato mostró una tendencia a aumentar e incrementar las concentraciones durante el período a inicios de 1990, aunque estos datos se debieron sin duda a anomalías metodológicas, y (5) la fitobiomasa mostró valores significativamente más altos durante el período de 1980. El aumento significativo en el fósforo total y la tendencia a aumentar del nitrato podría reflejar un aumento en el uso de praderas dentro de la cuenca de drenaje. Se detectaron una serie de anomalías en los datos históricos relacionadas a la metodología los cuales se analizaron y discutieron dentro del contexto de este estudio.

Palabras clave: eutrofización, lago patagónico, nutrientes, trofía, métodos analíticos. 


\section{INTRODUCTION}

The southern Chilean lake district from 39 to $42^{\circ}$ $\mathrm{S}$ is a region of deep, mostly oligotrophic lakes of glacial origin (Campos 1984, Campos et al. 1987). The lakes have maximum depths of 90 to $330 \mathrm{~m}$. The climate in this region is temperate and humid, with high annual mean rainfall (2-5 $\mathrm{m} \mathrm{yr}^{-1}$ ) (Soto \& Campos 1995). Lake Riñihue is representative of many of these lakes where their trophic status and productivity may increase with changes in land use within the catchment area (Campos 1984). Sediment and nutrient loads arriving in these lakes have increased in response to the replacement of native temperate forests by agriculture and inputs of wastewater derived from growing human populations (Oyarzún et al. 1997). In Lake Villarrica, for example, recent increases in agricultural and urban development in its catchment area have initiated the eutrophication of some lake embayments (Campos et al. 1983). Increased nitrogen and phosphorus loading into Lake Riñihue, mainly by diffuse sources, may also initiate eutrophication similar to that of other lakes and reservoirs (Campos 1984, Vila et al. 2000, Zhou et al. 2000). To evaluate this possibility, temporal changes of trophic parameters must be measured over a long period of time, since they describe the lake's trophic state, where the term "eutrophic" refers to lakes having enriched nutrient regimes, and high primary productivity, and "oligotrophic" lakes have low nutrient concentrations and low primary productivity (OECD 1982). The main nutrients of concern are phosphorus and nitrogen. If only nutrients are limiting, their increase may stimulate eutrophication, causing elevated concentrations of chlorophyll $a$, phytoplankton biomass and primary production. Eutrophication may often cause oxygen depletion in the deep layers of a lake, accompanied by decreases in light transmission as measured, for example, by Secchi depth (OECD, 1982).

Lake Riñihue was interest to us for two reasons: (1) there exists a large body of data on its key parameters collected by Campos and coworkers over the last two decades which has been only partially analysed and published (Campos et al. 1987, Woelfl 1995, Campos et al. 2001), and (2) because Lake Riñihue is the last in a chain of seven lakes and thus acts as an integrative indicator of changes within its catchment area, signalling the emergence of eutrophication processes.

Löffler (1960) conducted the first intensive survey of the chemistry of North Patagonian lakes in 1954 and recorded extremely low levels of inorganic phosphorus in Lake Riñihue $\left(\sim 1 \mu \mathrm{g} \mathrm{L}^{-1}\right)$. Campos et al. (1987) classified Lake Riñihue as oligotrophic but changes in land use suggest that its trophic status may be changing. Due to its very large catchment area, the lake appears to be one of the most sensitive to anthropogenic effects among all the North Patagonian lakes (Campos 1984, Soto \& Campos 1995).

Recently, Campos et al. (2001) examined the lake's thermal structure and heat budget in detail in order to understand its stratification and mixing regime, and the interaction of these with phytoplankton and nutrient dynamics. In the study of lake Riñihue these authors coupled the hydrodynamic-water quality model, DYRESM-WQ to output water quality data at daily intervals. The DYRESM-WQ model comprises a hydrodynamic model and an ecological model, both of which have been described in detail in the literature (Imberger \& Patterson 1981, Hamilton \& Schladow 1997). The simulation output confirmed the oligotrophic nature of Lake Riñihue, the general timing of changes in chlorophyll $a$ and the depletion of dissolved inorganic nutrients from the surface layer during summer.

An extensive database on physical, chemical and biological parameters of Lake Riñihue collected from 1970 to 1997 was left behind by Prof. Hugo Campos upon his untimely death in 1998. The present study reviews his data and the data of other workers in an attempt to present a comprehensive overview of limnological parameters for Lake Riñihue, analysing trophic parameters such as nitrogen and phosphorus, chlorophyll $a$, phytoplankton biomass, primary production and Secchi depth (SDT) as potential indicators of significant changes in the trophic state of the lake over the study period. Because during the data validation we identified some methodological problems related to almost all parameters, part of this study included careful reviews of all methods employed, identification of anomalies in historical data, rectification of anomalous data where possible, and discarding of questionable data.

\section{MATERIAL AND METHODS}

\section{Study site}

Lake Riñihue is an oligotrophic lake located $\sim 117 \mathrm{~m}$ above sea level at $39^{\circ} 50^{\prime} \mathrm{S}, 72^{\circ} 20^{\prime} \mathrm{W}$. The lake is the last in a chain of six lakes 
(Lacar, Pirehueico, Neltume, Panguipulli, Calafquén, Pellaifa) having the San Pedro river as a single major outflow (Fig. 1). The catchment area of Lake Riñihue is $4,500 \mathrm{~km}^{2}$ of which $\sim 3,900 \mathrm{~km}^{2}$ originates from the from Enco river and the remainder from a few small streams. The theoretical water renewal time of Lake Riñihue is approximately one year and its surface water temperatures typically range from 9 to $20{ }^{\circ} \mathrm{C}$ during the year. There is significant thermal stratification $\left(>2-3{ }^{\circ} \mathrm{C}\right.$ ) for $9-10$ months of the year, beginning in September (Campos et al. 1978, 1987, Woelfl 1995). Dissolved oxygen concentrations are always close to saturation throughout the water column and transparency is high (Campos et al. 1987, 1998, Geller 1992, Woelfl 1995).

\section{Water sampling}

Water samples for chemical and biological analyses were taken from different depths in the western part of the lake where the depth is over 110 (Fig. 1) using a Van Dorn sampler (Table 1).

The sampling intervals in different years varied from weekly to monthly as given in Table 1.

\section{Analyses of nutrients and total phosphorus}

Nutrients were determined by colorimetric analyses. For phosphorus analysis we used the stannous chloride method during 1978-1979 and the ascorbic acid method during 1984-1997 with a preliminary acid-peroxide digestion step for total phosphorus (APHA 1992). Absorbance was measured in a Spectronic 100 spectrophotometer using a $20 \mathrm{~mm}$ cylindrical cell (1978-1979) and in a UV-150-02 Shimadzu spectrophotometer using a $100 \mathrm{~mm}$ rectangular long-path cells (1984-1997). Nitrate was measured with the sodium salicylate and Seignette salt method (Campos et al. 1987).

To check whether the sample storage or the use of different plastic bottles influenced the

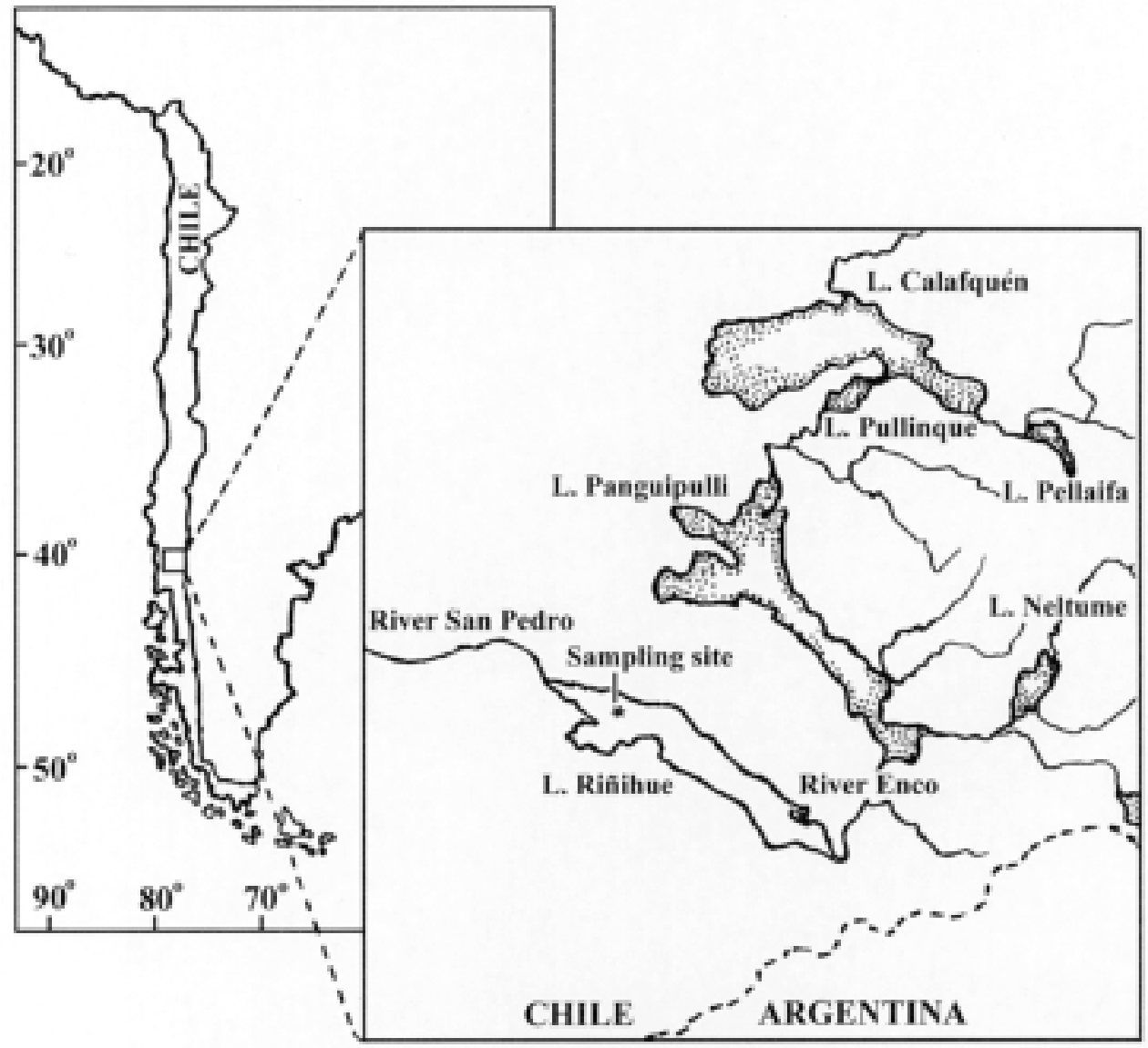

Fig. 1: Location of Lake Riñihue (southern Chile).

Localización del lago Riñihue (sur de Chile). 


\section{TABLE 1}

Period, year number, sampling period and interval and sampling depths in Lake Riñihue during 1978-1997:

PP: primary production, phyto: phytoplankton biomass

\begin{tabular}{lccccc}
\multicolumn{1}{c}{ Periodo, número de año, periodo e intervalo de muestreo y profundidades de muestreo en el Lago Riñihue durante 1978-1997: } \\
PP: productividad primaria: phyto: fitobiomasa
\end{tabular}

analyses of nutrients and TP, from November 1990 to January 1991 water was sampled in two different plastic bottles. Groups of water samples were (i) analysed immediately and (ii) after storage for 3 days at $-20{ }^{\circ} \mathrm{C}$ temperature.

\section{Determination of the phytoplankton biomass}

The phytoplankton was collected in $160 \mathrm{ml}$ glass bottles, preserved in Lugol's solution and counted using the Utermöhl method in an inverted microscope (Zeiss). For biomass estimates the biovolume was calculated assuming a rotational ellipsoid shape and finally converted to fresh weight (1 pg fresh weight $\mu \mathrm{m}^{-3}$ ).

\section{Determination of chlorophyll a}

Over the lengthy period now being reported, methods for chlorophyll $a$ varied slightly between two periods. In general, chlorophyll $a$ was determined by filtration of lake water through Millipore ${ }^{\circledR}$ glass fibre $(\mathrm{GF} / \mathrm{C})$ filters.
During 1978-1979 the filters were kept two to four days at $4{ }^{\circ} \mathrm{C}$ in the dark before pigment extraction with $90 \%$ acetone (Campos et al. 1987, G. Agüero personal communication). From the 1980's on the pigment extraction was applied immediately after the filtration procedure and extraction allowed for a minimum of $24 \mathrm{~h}$. Finally, absorbance of the extract was measured with a Spectronic 100 spectrophotometer (1978-1979) or a Shimadzu UV-150-02 spectrophotometer (1984-1997). The equations of SCOR-UNESCO (1969) were then used to estimate concentrations of chlorophyll $a$ after correction for accessory pigments (chlorophyll $b$ and $c$ ). Chlorophyll $a$ data presented here were not corrected for phaeopigments.

\section{Determination of primary production rates}

Primary production (PP) was measured using the ${ }^{14} \mathrm{C}$-method. Water samples were incubated in situ with $2.5-10 \mu \mathrm{Ci}^{14} \mathrm{C}$-carbonate per 100 mL-bottle for $4 \mathrm{~h}$ during midday. After $4 \mathrm{~h}$, the 
incubation was terminated and the samples were filtered through glass fibre filters (19781979), millipore HA filters (1984-1988) or 0.2$0.45-\mu \mathrm{m}$ Nuclepore filters (1990-1992). Filters were acidified within fumes of concentrated $\mathrm{HCl}$ to remove excess ${ }^{14} \mathrm{CO}_{2}$. After adding 10 $\mathrm{mL}$ of scintillation fluid, the vials were counted in a Chicago Scintillation counter (1978-1988) or a Beckman LS 5000 CE Scintillation counter (1990-1992).

The calculation of the concentration of dissolved inorganic carbon (DIC) which is needed for the estimation of the primary production was done based on the alkalinity which was determined by titration with $0.1 \mathrm{~N}$ (August 1978-March 1985) and 0.025 N (April 1985-1997) hydrochloric acid against Bromocresol-Methyl green indicator. According to the original protocols DIC was calculated using two different methods: (1) 1978-March 1985,

$\mathrm{mg}$ DIC $\mathrm{m}^{-3}=A \times N \times 50.000 \times 120 / \mathrm{mL}$ sample (equation 1 )

where $A=\mathrm{mL}$ hydrochloric acid used, and $N=$ normality of hydrochloric acid used; (2) April 1985-1992,

mg DIC $\mathrm{m}^{-3}=$ carbonate alkalinity $\left(\mathrm{meq}^{-1}\right) \times F$ x 12000 (equation 2)

where $F=$ factor for conversion of carbonate alkalinity to total carbon dioxide in mmol per litre (according to $\mathrm{pH}$, temperature and ionic strength). The value of $F$ generally ranged from 1.01 to 1.35 . Carbonate alkalinity was assumed to be total alkalinity at $\mathrm{pH}<8.2$. Photosynthesis rates finally were calculated according to standard methodology (Dokulil 1984, APHA 1992).

\section{Statistical analyses}

Statistical analyses were made on values representing the upper $25 \mathrm{~m}$ of the water column (epilimnion) for all parameters, and additionally for the $0-40 \mathrm{~m}$ depth interval for phytoplankton biomass, chlorophyll a and PP. To detect and remove outliers for further statistical analyses, the median-quartiles test of the SPSS V.7.5 statistical package were applied. Outliers and extremes are defined between $1.5 \mathrm{x}$ and $3 \mathrm{x}$ the upper or lower edge of the box which represents the interquartile range $(25-75 \%)$. To test for significant differences between geometrical means of periods and years, the non-parametric Wilcoxon score test
(Rank Sum) was used (SAS-Statistical package $\mathrm{V}$ 6.12). The significance/non-significance of the different treatments of the freezer experiments were tested using the Student t-test (significance level $\mathrm{P}<0.05$ ).

\section{RESULTS AND DISCUSSION}

\section{Analyses of the data base}

The review of the extensive database revealed that almost all the parameters often showed large variations within short time intervals (Fig. 2 and 4). In part, this was caused by methodological problems which in many cases were related to changes and/or improper use of methods. Consequently, this caused serious problems in the validation and correction of the data, and the final statistical analyses. For clarity, we have omitted details of our procedural methods and only present (i) the final database obtained and our approximations of the temporal changes in the trophic parameters (ii) and a brief review of the methodological complications and their resolution.

The trophic parameters were analysed in groups of four periods and of eight years (Tables 3-6). Every period and year was tested for significant differences between pairs of samples. Whereas significant differences between periods of several years may better reflect general temporal trends, year to year comparisons are more influenced by inter-annual variations. These differences are not only caused by year to year changes, but also by different sampling intervals and the sampling periods (see Table 1). In this case, almost all sampling periods (years) started and ended during different seasons. Thus, temporal trends derived from year to year comparisons are less conclusive than comparisons between periods.

Long-term changes I: nutrients and total phosphorus

Figure 2 and 3 show the average (weighted) concentrations of nitrate, SRP and TP in the upper $25 \mathrm{~m}$ water column for every sampling day and for every year. With exception of the early 1990 period, nitrate showed very similar concentrations during the 1980 period and the mid 1990 period fluctuating between 4.4 and 8.2 $\mu \mathrm{g} \mathrm{N} \mathrm{L}{ }^{-1}$ (Table 2, Fig. 3). These values are comparable to those found for Chilean and Andean Argentinian lakes (Quiros 1988, Donoso \& Phinney 1987, Campos et al. 1992b, Pedrozo 

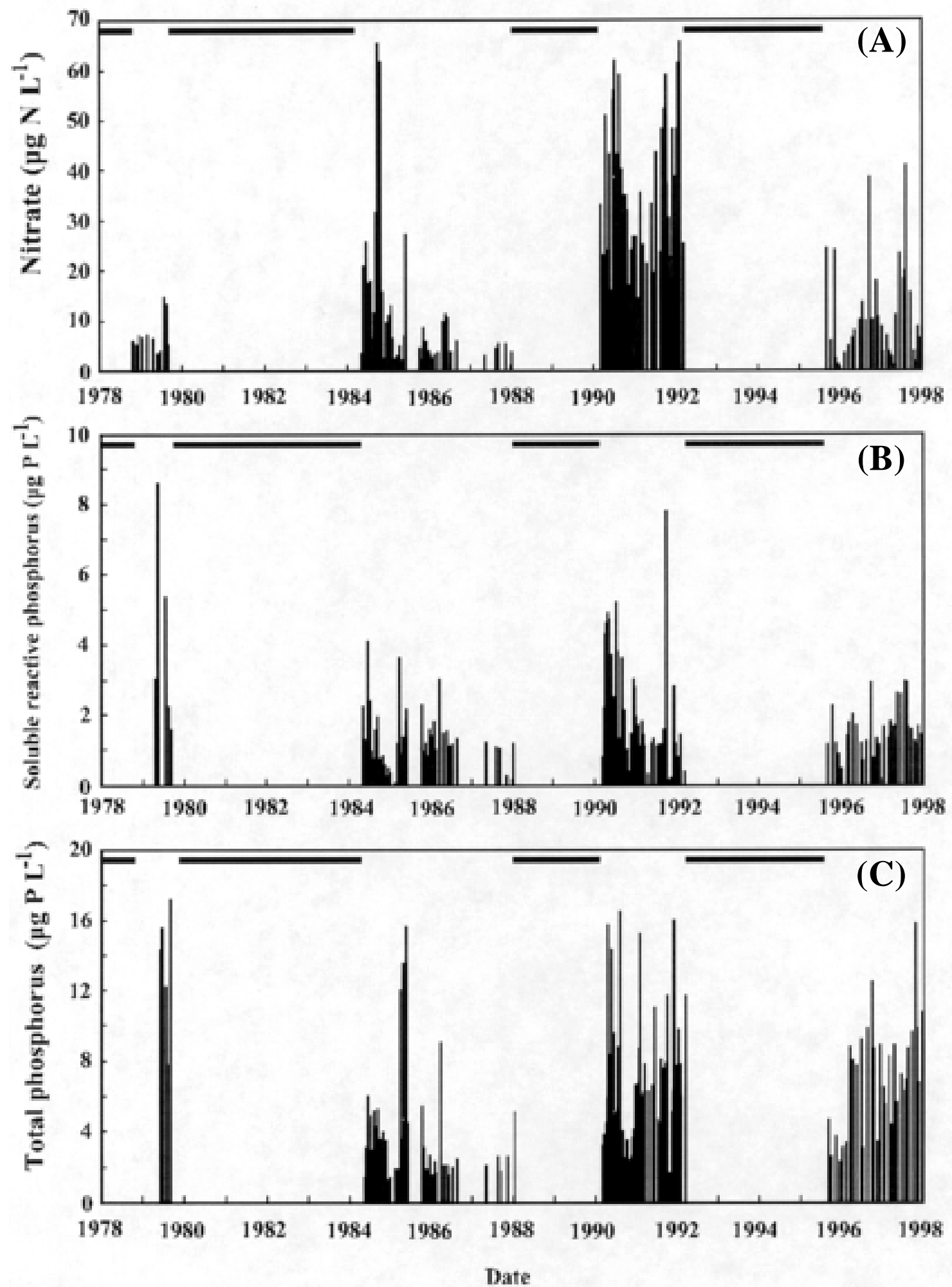

Fig. 2: Nitrate (A), soluble reactive phosphorus (B) and total phosphorus (C) in Lake Riñihue during 1978-1997. Values correspond to the average concentrations of the upper $25 \mathrm{~m}$ water column. Horizontal lines indicate periods without data.

Nitrato (A), fósforo reactivo soluble (B) y fósforo total (C) en el Lago Riñihue durante 1978-1997. Valores corresponden a los promedios de los primeros $25 \mathrm{~m}$ de la columna de agua. Las líneas horizontales indican periodos sin datos. 


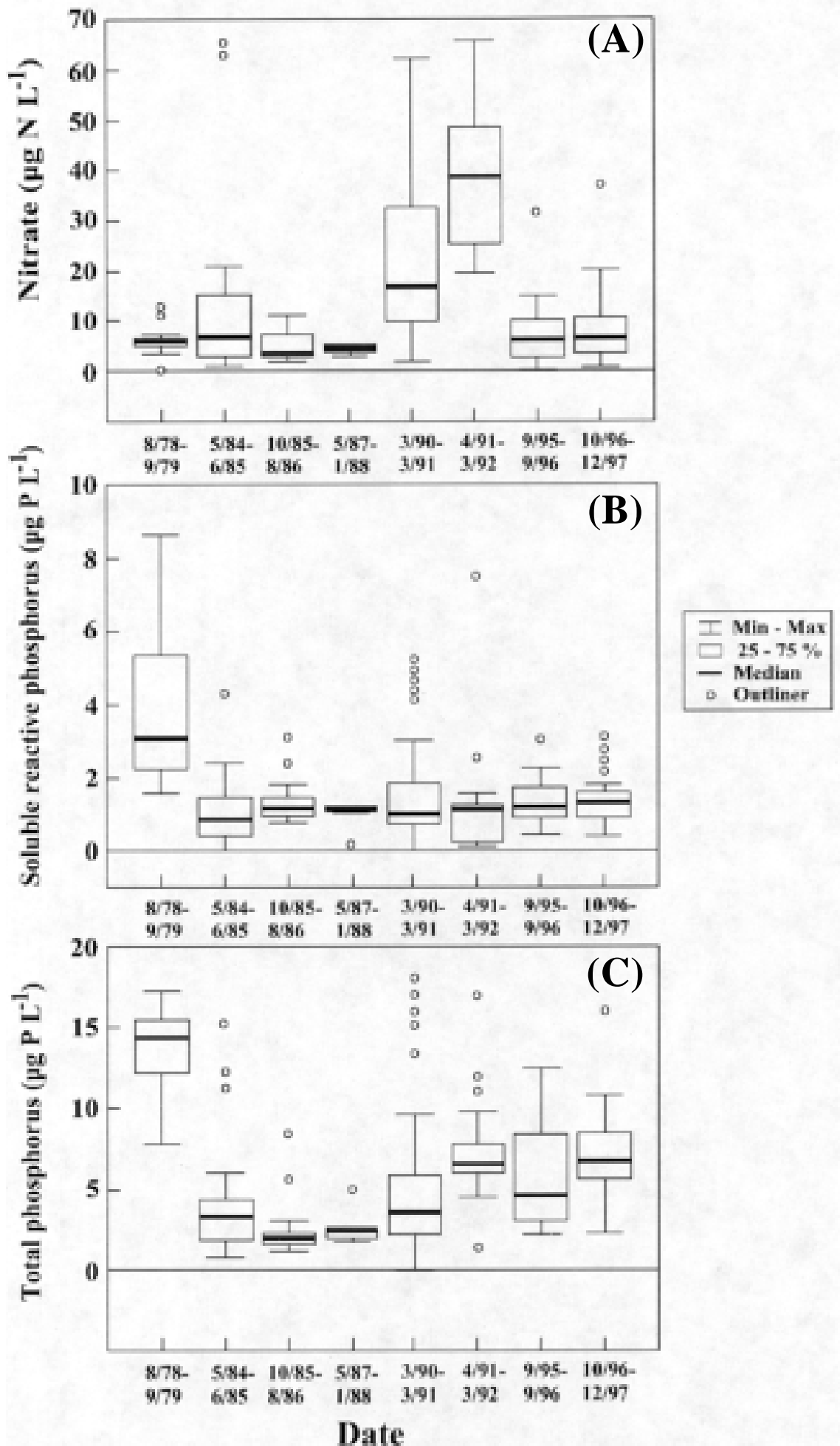

Fig. 3: Box \& whisker plots excluding outliers and extremes of nitrate (A), soluble reactive phosphorus (B) and total phosphorus (C) in Lake Riñihue during 1978-1997. Values correspond to the upper 25 m water column.

Diagramas de "box \& whisker" excluyendo los valores fuera de rango ("outliers") y valores extremos de nitrato (A), fósforo reactivo soluble (B) y fósforo total (C) en el lago Riñihue durante 1978-1997. Values correspond to the upper $25 \mathrm{~m}$ water column. 

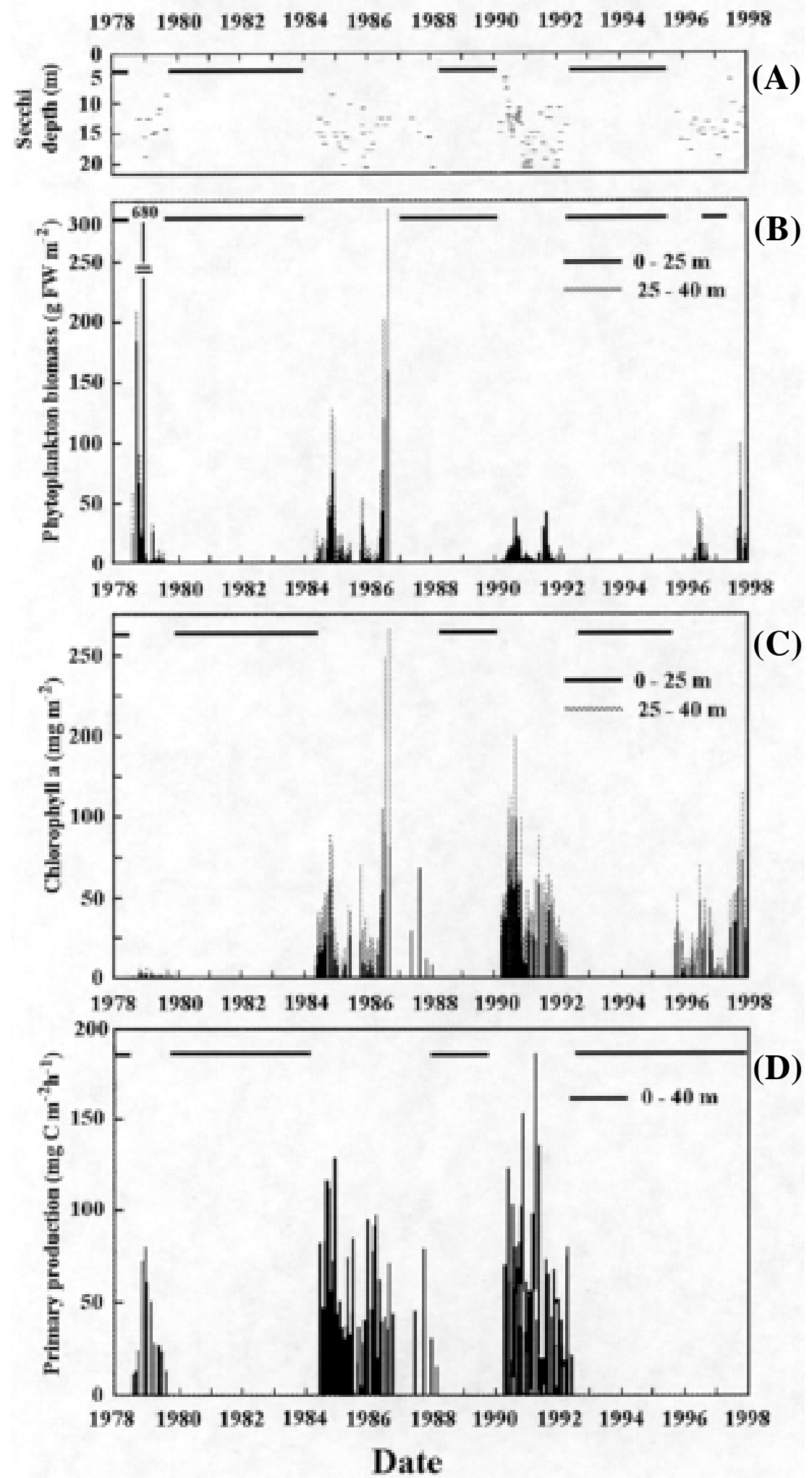

Fig. 4: Sechhi depth (A), phytoplankton biomass (B), chlorophyll a (C) and primary production (D) in Lake Riñihue during 1978-1997. Horizontal lines indicate periods without data.

Profundidad de Secchi (A), biomasa de fitoplancton (B), clorofila a (C) y productividad primaria (D) en el Lago Riñihue durante 1978-1997. Líneas horizontales indican periodos sin datos. 
TABLE 2

Means \pm SD (0-25 m) and medians of Secchi depth, nitrate, soluble reactive phosphorus (SRP) and total phosphorus (TP) in Lake Riñihue during 1978-1997. Outliers were excluded

Promedios \pm DE (0-25 m) y medianas de profundidad de Secchi, nitrato, fósforo reactivo soluble (SRP) y fósforo total (TP) en el Lago Riñihue durante 1978-1997. Los valores fuera de rango fueron excluidos

\begin{tabular}{|c|c|c|c|c|c|c|c|c|}
\hline Period No. and Year & Secchi depth & $\begin{array}{c}\mathrm{n} \\
(\mathrm{m})\end{array}$ & $\begin{array}{c}\text { Nitrate }\left(\mu \mathrm{g} \mathrm{N} \mathrm{L} \mathrm{L}^{-1}\right) \\
0-25 \mathrm{~m}\end{array}$ & $\mathrm{n}$ & $\begin{array}{c}\mathrm{SRP}(\mu \mathrm{g} \mathrm{P} \mathrm{L}-1) \\
0-25 \mathrm{~m}\end{array}$ & $\mathrm{n}$ & $\begin{array}{c}\mathrm{TP}\left(\mu \mathrm{g} \mathrm{P} \mathrm{L}^{-1}\right) \\
0-25 \mathrm{~m}\end{array}$ & $\mathrm{n}$ \\
\hline $\begin{array}{l}\text { 1: Late } 1970 \text { 's } \\
\text { Sep 1978-Sep } 1979\end{array}$ & $\begin{array}{l}12.3 \pm 2.4 \\
12.5\end{array}$ & $\begin{array}{r}9 \\
5.9\end{array}$ & $\begin{array}{c}5.8 \pm 1.4 \\
3.1\end{array}$ & $\begin{array}{r}9 \\
14.3\end{array}$ & $4.2 \pm 2.9$ & 5 & $13.4 \pm 3.6$ & 5 \\
\hline 2: The 1980's & $\begin{array}{c}13.3 \pm 3.2 \\
13.0\end{array}$ & 44 & $\begin{array}{c}7.1 \pm 5.3 \\
5.1\end{array}$ & 42 & $\begin{array}{c}1.1 \pm 0.6 \\
1.1\end{array}$ & 39 & $\begin{array}{c}2.7 \pm 1.3 \\
2.3\end{array}$ & 39 \\
\hline May 1984-Jun 1985 & $\begin{array}{c}12.9 \pm 3.6 \\
13\end{array}$ & 24 & $\begin{array}{c}9.1 \pm 6.4 \\
7.0\end{array}$ & 21 & $\begin{array}{c}1.0 \pm 0.7 \\
0.8\end{array}$ & 21 & $\begin{array}{c}3.2 \pm 1.5 \\
3.3\end{array}$ & 21 \\
\hline Oct 1985-Aug 1986 & $\begin{array}{c}13.7 \pm 2.7 \\
13.2\end{array}$ & 16 & $\begin{array}{c}5.2 \pm 3.1 \\
3.9\end{array}$ & 16 & $\begin{array}{c}1.2 \pm 0.3 \\
1.2\end{array}$ & 14 & $\begin{array}{c}2.0 \pm 0.59 \\
1.9\end{array}$ & 14 \\
\hline May 1987-Jan 1988 & $\begin{array}{c}14.2 \pm 3.4 \\
13.5\end{array}$ & 4 & $\begin{array}{c}4.4 \pm 1.0 \\
4.5\end{array}$ & 5 & $\begin{array}{c}1.1 \pm 0.1 \\
1.1\end{array}$ & 4 & $\begin{array}{c}2.3 \pm 0.4 \\
2.4\end{array}$ & 4 \\
\hline 3: Early 1990's & $\begin{array}{l}12.8 \pm 3.8 \\
12.7\end{array}$ & 68 & $\begin{array}{l}26.4 \pm 17.2 \\
\quad 23.0\end{array}$ & 69 & $\begin{array}{c}1.1 \pm 0.7 \\
1.1\end{array}$ & 59 & $\begin{array}{c}4.5 \pm 2.5 \\
4.0\end{array}$ & 62 \\
\hline Mar 1990-Mar 1991 & $\begin{array}{c}12.6 \pm 3.9 \\
12\end{array}$ & 49 & $\begin{array}{c}22.0 \pm 15.7 \\
16.9\end{array}$ & 52 & $\begin{array}{c}1.2 \pm 0.8 \\
1.0\end{array}$ & 43 & $\begin{array}{c}3.9 \pm 2.4 \\
3.5\end{array}$ & 49 \\
\hline Apr 1991-Mar 1992 & $\begin{array}{c}13.5 \pm 3.4 \\
13\end{array}$ & 19 & $\begin{array}{l}39.9 \pm 14.9 \\
38.7\end{array}$ & 17 & $\begin{array}{c}0.9 \pm 0.5 \\
1.1\end{array}$ & 16 & $\begin{array}{l}6.8 \pm 1.5 \\
6.6\end{array}$ & 13 \\
\hline 4: Mid 1990’s & $\begin{array}{l}12.8 \pm 3.2 \\
12.8\end{array}$ & 27 & $\begin{array}{c}7.7 \pm 5.6 \\
6.4\end{array}$ & 40 & $\begin{array}{c}1.3 \pm 0.4 \\
1.3\end{array}$ & 38 & $\begin{array}{c}6.5 \pm 2.6 \\
6.7\end{array}$ & 44 \\
\hline Sep 1995-Sep 1996 & $\begin{array}{c}13.4 \pm 2.7 \\
12.9\end{array}$ & 12 & $\begin{array}{c}6.7 \pm 4.7 \\
6.2\end{array}$ & 12 & $\begin{array}{c}1.3 \pm 0.5 \\
1.2\end{array}$ & 14 & $\begin{array}{c}5.8 \pm 3.3 \\
4.6\end{array}$ & 15 \\
\hline Oct 1996-Dec 1997 & $\begin{array}{l}12.4 \pm 3.6 \\
12.5\end{array}$ & 15 & $\begin{array}{l}8.2 \pm 6.0 \\
\quad 6.6\end{array}$ & 28 & $\begin{array}{c}1.2 \pm 0.4 \\
1.3\end{array}$ & 24 & $\begin{array}{c}6.8 \pm 2.1 \\
6.8\end{array}$ & 29 \\
\hline
\end{tabular}

et al. 1993, Díaz et al. 2000, Soto 2002). The much higher nitrate concentrations during the early 1990 period (annual means: $22-39.9 \mu \mathrm{g} \mathrm{N}$ $\mathrm{L}^{-1}$ ) may have been caused by anomalous methodology, discussed below. Because the nitrate concentrations varied greatly during this period, the existence of outliers was unclear (see Fig. 3). All years and periods were significantly different from the early 1990 period (Tables 3 and 4). However, this finding should not be interpreted as real differences between the periods because of the doubtful nitrate values during the early 1990 period. Excluding the data set of the early 1990 period, there is a weak upward trend of increasing nitrate concentrations during the last two decades (see median Fig. 3), although this is still not significant. In contrast to our results, Campos et al. (1992a) reported a six fold increase of nitrate during 1976 to 1983 (3.63 to $15.4 \mu \mathrm{g} \mathrm{N} \mathrm{L}^{-1}$ ) for Lake Ranco. These data, however, also need to be checked for methodological problems.

SRP varied little during the 1980 and 1990 periods (data from 1978/79 excluded) showing values of about 1-1.5 $\mu \mathrm{g} \mathrm{P} \mathrm{L} \mathrm{L}^{-1}$. These concentrations are in the same range as found for other north Patagonian lakes (Campos et al. 1988, 1989, 1990, 1992a, 1992b, Quiros 1988, Pedrozo et al. 1993, Díaz et al. 1998, Soto 2002). No significant long-term changes between periods were observed. The significant changes of SRP, found during the 1990 period, were very small $\left(0.2-0.3 \mu \mathrm{g} \mathrm{P} \mathrm{L}^{-1}\right)$.

Total phosphorus clearly showed the only significant and continuous increase during the 1980 and 1990 periods with values rising from 2.7 to $6.5 \mu \mathrm{g} \mathrm{P} \mathrm{L}^{-1}$ (Tables 2). All observations support this conclusion (Tables 3 and 4).

Long-term changes II: Secchi depth, phytoplankton biomass, chlorophyll a and primary production

SDT fluctuated very little between 12.3 and $14.2 \mathrm{~m}$ (annual average) during the entire study period (Table 2). There was no significant change between different years or periods (Tables 3 an 4).

During the 1980 period the phytoplankton biomass showed its highest peaks for both the 


\section{TABLE 3}

Two-sample Wilcoxon rank-sum tests for differences between the means of two periods for trophic parameters in Lake Riñihue during 1978-1997. Arrows indicate the periods with significant differences of their means $(\mathrm{P}>|\mathrm{Z}|: \mathrm{a}<0.05)$

Prueba de Wilcoxon de dos muestras para diferencias entre los promedios de dos periodos para parámetros tróficos en el Lago Riñihue durante 1978 y 1997. Las flechas indican los periodos con diferencias significativas de sus promedios $(\mathrm{P}>|\mathrm{Z}|$ : $a<0,05)$

\begin{tabular}{|c|c|c|c|c|c|}
\hline Parameter & Depth interval (m) & Late 1970 's & The 1980's & Early 1990’s & Mid 1990's \\
\hline \multirow[t]{2}{*}{ Nitrate } & $0-25$ & & \multicolumn{3}{|c|}{$-\uparrow$} \\
\hline & & & \multicolumn{3}{|c|}{ 个 } \\
\hline SRP & $0-25$ & Data excluded & \multicolumn{3}{|c|}{ No differences detected } \\
\hline TP & $0-25$ & Data excluded & $\uparrow$ & $\uparrow$ & \multirow[t]{2}{*}{$-\uparrow$} \\
\hline SDT & & \multicolumn{3}{|c|}{ No differences detected } & \\
\hline \multicolumn{6}{|c|}{ Phytoplankton } \\
\hline \multirow[t]{2}{*}{ biomass } & $0-25$ & Data excluded & $\uparrow$ & $\uparrow$ & \\
\hline & $0-40$ & Data excluded & \multicolumn{3}{|c|}{ No differences detected } \\
\hline \multirow[t]{2}{*}{ Chl $a$} & $0-25$ & Data excluded & \multicolumn{3}{|c|}{$\uparrow$} \\
\hline & $0-40$ & Data excluded & \multirow{3}{*}{$-\uparrow$} & $\uparrow$ & $-\uparrow$ \\
\hline \multirow[t]{2}{*}{ PP } & $0-25$ & $\uparrow$ & & & \\
\hline & $0-40$ & $\uparrow_{-}$ & & $-\uparrow$ & No data \\
\hline
\end{tabular}

TABLE 4

Two-sample Wilcoxon rank-sum tests for differences between the means of two years for nitrate, SRP and TP in Lake Riñihue during 1978-1997. Arrows indicate the years with significant differences of their means $(\mathrm{P}>|\mathrm{Z}|: \mathrm{a}<0.05)$

Pruebas de Wilcoxon de dos muestras para diferencias entre los promedios de dos años para nitrato, FSR y TP en el Lago Riñihue durante 1978 y 1997. Las flechas indican los años con diferencias significativas de sus promedios $(\mathrm{P}>|\mathrm{Z}|$ : $\mathrm{a}<0,05)$

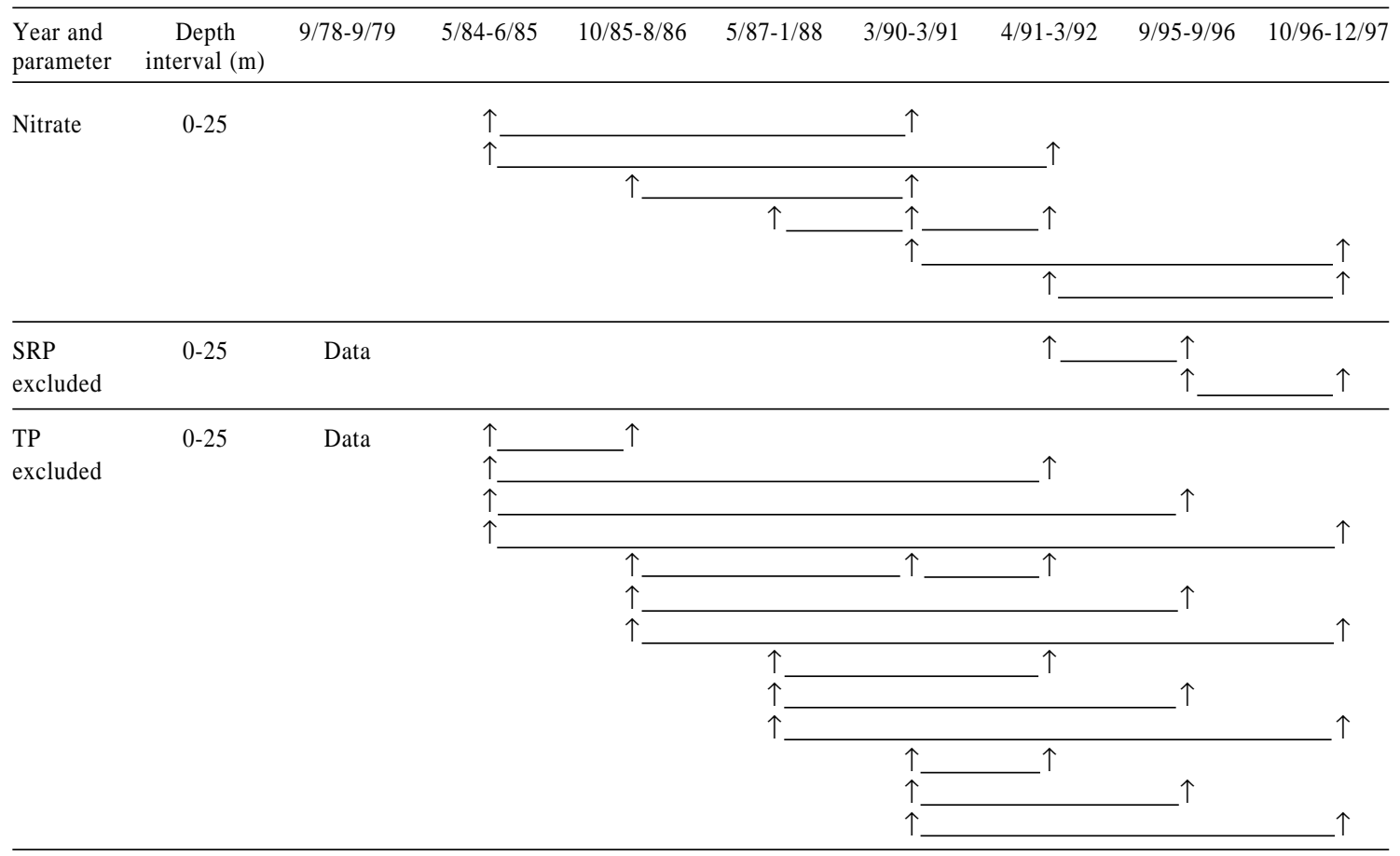


0-25 $\mathrm{m}$ and the 0-40 $\mathrm{m}$ depth intervals (Fig. 4, 5 , Table 6). The mean phytoplankton biomass was highest during the 1980 period $(0-40 \mathrm{~m})$. Nevertheless, no significant temporal trends were observed between periods or years (Tables 3 and 5). Considering only the epilimnion (0-25 $\mathrm{m}$ ) the phytoplankton biomass was about $3 \mathrm{x}$ and $2 \mathrm{x}$ higher during the 1980 period compared to the early 1990 period and the mid 1990 period (Table 6). Significant differences were found between the mid 1980 period and the early 1990 period, but not between the early 1990 period and the mid 1990 period (Tables 3 and 4).

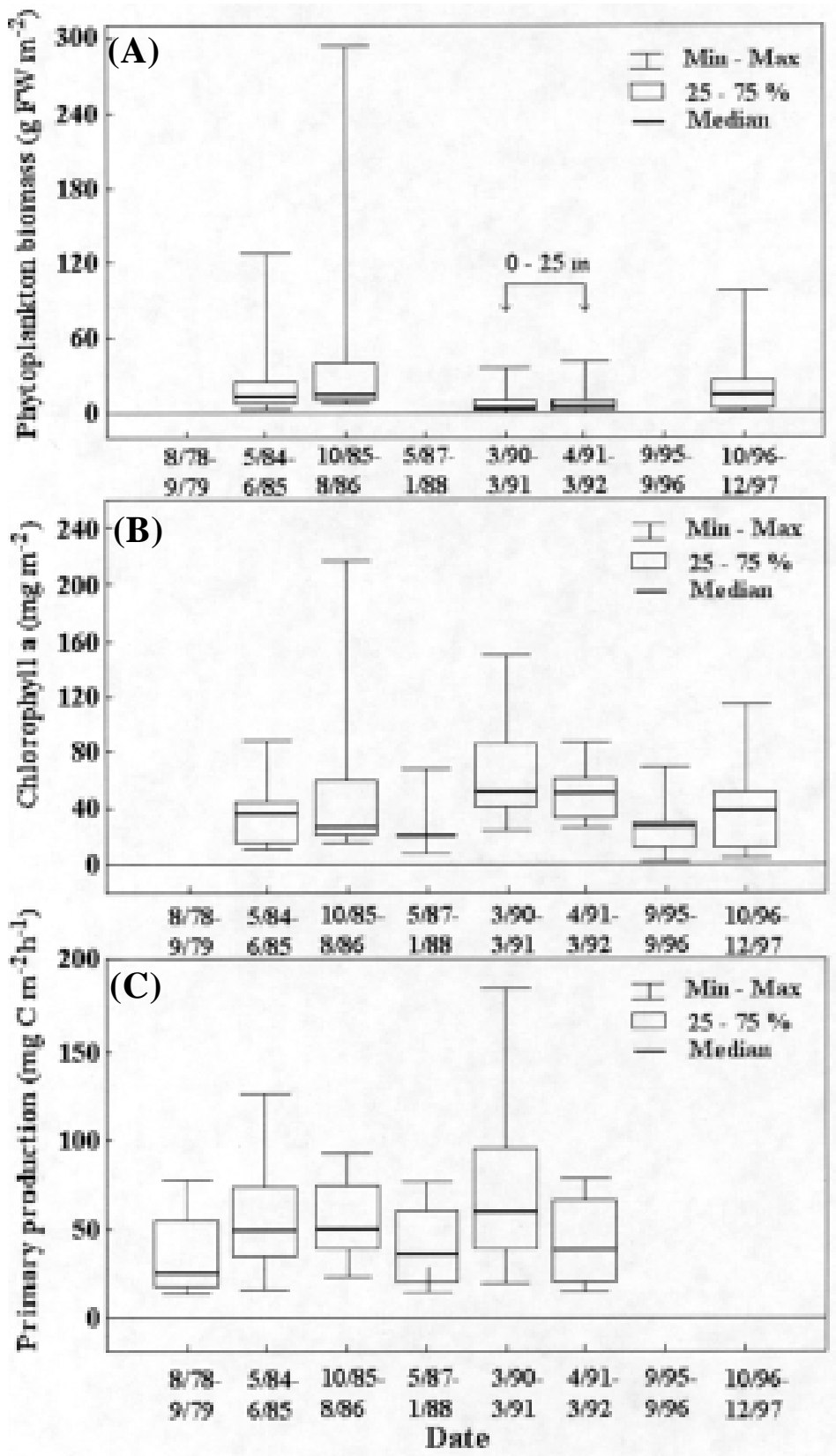

Fig. 5: Box \& whisker plots of the phytoplankton biomass (A), chlorophyll a (B) and primary production (C) in Lake Riñihue during 1978-1997. Values correspond to the depths intervals 0-40 $\mathrm{m}$, if not indicate otherwise.

Diagramas de "box \& whisker" de la biomasa de fitoplancton (A), clorofila a (B) y producción primaria (C) para los intervalos 0-25 m (a) y 0-40 m en el Lago Riñihue durante 1978-1997. Los valores corresponden a los intervalos de profundidad 0-40 $\mathrm{m}$, si no se indica otra cosa. 


\section{TABLE 5}

Two-sample Wilcoxon rank-sum tests for differences between the means of two years for nitrate, SRP and TP in Lake Riñihue during 1978-1997. Arrows indicate the years with significant differences of their means $(\mathrm{P}>|\mathrm{Z}|: \mathrm{a}<0.05)$

Prueba de Wilcoxon de dos muestras para diferencias entre los promedios de dos años para nitrato, FSR y TP en el Lago Riñihue durante 1978 y 1997. Las flechas indican los años con diferencias significativas de sus promedios $(\mathrm{P}>|\mathrm{Z}|: \mathrm{a}<0,05)$

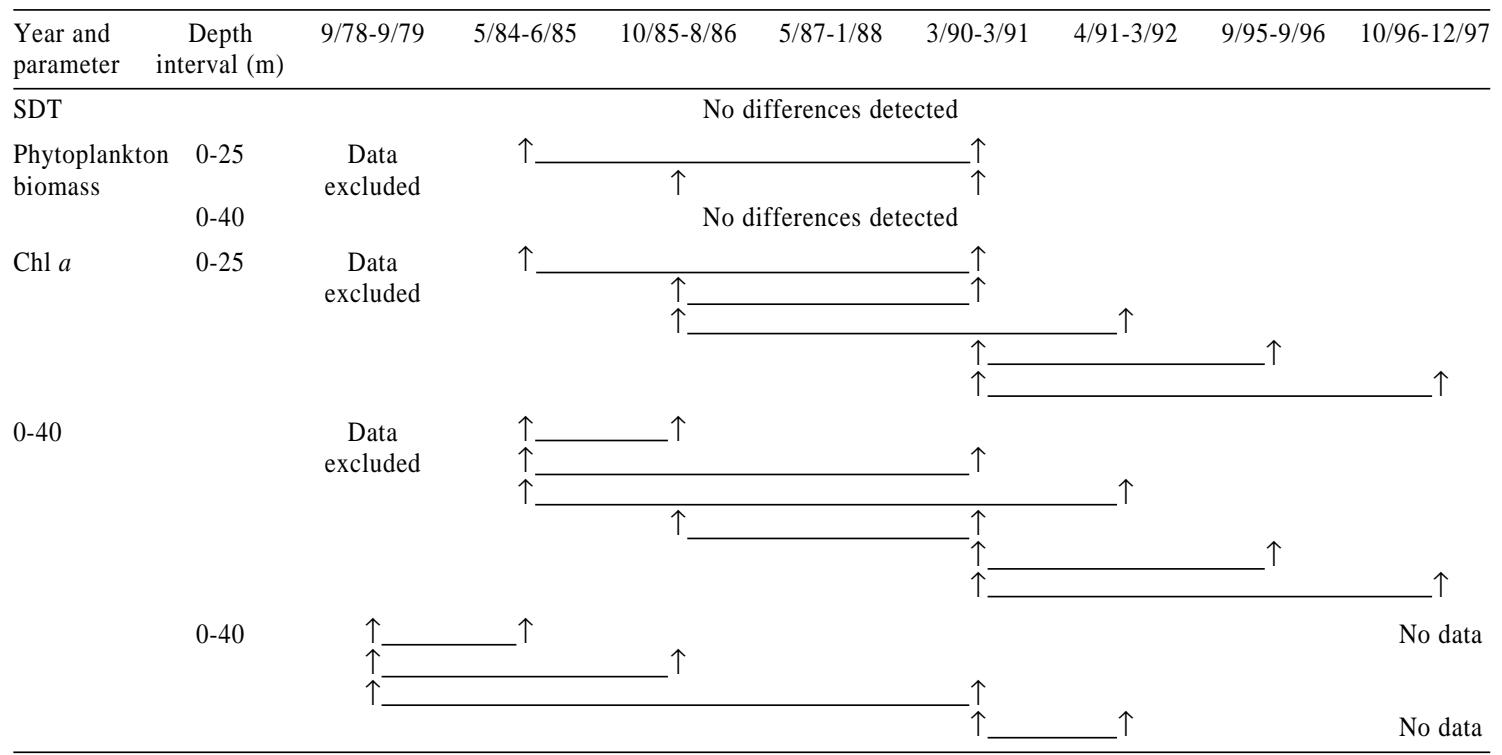

TABLE 6

Means \pm SD and medians of phytoplankton biomass, chlorophyll $a$, primary production (PP) and in Lake Riñihue during 1978-1997

Promedios \pm DE y medianas de biomasa fitoplanctónica, clorofila $a$, producción primaria (PP) y en el Lago Riñihue durante 1978-1997

\begin{tabular}{|c|c|c|c|c|c|c|c|c|}
\hline \multirow[b]{2}{*}{ Period $\mathrm{N}^{0}$ and Year } & \multicolumn{3}{|c|}{ Phytoplankton biomass ( $\mathrm{g} \mathrm{FW} \mathrm{m}^{-2}$ ) } & \multicolumn{2}{|c|}{ Chlorophyll $a\left(\mathrm{mg} \mathrm{m}^{-2}\right)$} & \multicolumn{3}{|c|}{ 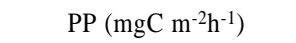 } \\
\hline & $0-25 \mathrm{~m}$ & $0-40 \mathrm{~m}$ & $\mathrm{n}$ & $0-25 \mathrm{~m}$ & $0-40 \mathrm{~m}$ & $\mathrm{n}$ & $0-40 \mathrm{~m}$ & $\mathrm{n}$ \\
\hline $\begin{array}{l}\text { 1: Late 1970's } \\
\quad \text { Sep 1978-Sep } 1979\end{array}$ & & & & $\begin{array}{c}1.9 \pm 1.2 \\
1.7\end{array}$ & $\begin{array}{c}3.6 \pm 2.1 \\
3.0\end{array}$ & 14 & $\begin{array}{c}34.0 \pm 23.7 \\
24.8\end{array}$ & 12 \\
\hline 2: The 1980's & $\begin{array}{c}21.6 \pm 33.4 \\
8.1\end{array}$ & $\begin{array}{c}35.5 \pm 57.9 \\
12.8\end{array}$ & 40 & $\begin{array}{c}26.8 \pm 25.0 \\
18.5\end{array}$ & $\begin{array}{c}42.8 \pm 41.9 \\
30.4\end{array}$ & 46 & $\begin{array}{c}56.0 \pm 27.4 \\
\quad 47.2\end{array}$ & 46 \\
\hline May 1984-Jun 1985 & $\begin{array}{c}17.2 \pm 21.7 \\
8.1\end{array}$ & $\begin{array}{c}26.2 \pm 33.8 \\
12.8\end{array}$ & 24 & $\begin{array}{c}24.0 \pm 15.6 \\
22.7\end{array}$ & $\begin{array}{l}36.7 \pm 21.7 \\
36.4\end{array}$ & 26 & $\begin{array}{c}57.7 \pm 30.6 \\
48.9\end{array}$ & 24 \\
\hline Oct 1985-Aug 1986 & $\begin{array}{c}28.2 \pm 45.9 \\
7.6\end{array}$ & $\begin{array}{c}49.5 \pm 81.3 \\
13.3\end{array}$ & 16 & $\begin{array}{c}30.4 \pm 35.9 \\
13.2\end{array}$ & $\begin{array}{c}56.3 \pm 63.5 \\
27.2\end{array}$ & 16 & $\begin{array}{c}57 . .3 \pm 22.1 \\
49.3\end{array}$ & 16 \\
\hline May 1987-Jan 1988 & & & & $\begin{array}{l}30.7 \pm 27.6 \\
\quad 23.4\end{array}$ & $\begin{array}{l}28.9 \pm 27.4 \\
20.0\end{array}$ & 4 & $\begin{array}{c}40.2 \pm 27.2 \\
35.5\end{array}$ & 4 \\
\hline 3: Early 1990’s & $\begin{array}{c}7.2 \pm 8.3 \\
4.0\end{array}$ & & 74 & $\begin{array}{c}38.4 \pm 19.9 \\
\quad 36.2\end{array}$ & $\begin{array}{l}59.8 \pm 28.4 \\
51.4\end{array}$ & 39 & $\begin{array}{c}63.1 \pm 38.5 \\
58.3\end{array}$ & 36 \\
\hline Mar 1990-Mar 1991 & $\begin{array}{c}6.7 \pm 7.1 \\
3.9\end{array}$ & & 54 & $\begin{array}{l}40.8 \pm 21.4 \\
\quad 37.7\end{array}$ & $\begin{array}{c}63.4 \pm 30.9 \\
51.3\end{array}$ & 28 & $\begin{array}{c}70.9 \pm 41.1 \\
59.6\end{array}$ & 28 \\
\hline Apr 1991-Mar 1992 & $\begin{array}{c}8.9 \pm 10.9 \\
5.6\end{array}$ & & 20 & $\begin{array}{l}32.2 \pm 14.2 \\
\quad 24.2\end{array}$ & $\begin{array}{l}50.7 \pm 18.6 \\
51.5\end{array}$ & 11 & $\begin{array}{c}44.0 \pm 22.9 \\
39.5\end{array}$ & 11 \\
\hline 4: Mid 1990's & $\begin{array}{c}13.0 \pm 16.0 \\
8.2\end{array}$ & $\begin{array}{c}21.3 \pm 25.7 \\
14.3\end{array}$ & 14 & $\begin{array}{c}21.6 \pm 17.4 \\
18.4\end{array}$ & $\begin{array}{l}32.9 \pm 26.2 \\
28.5\end{array}$ & 28 & & \\
\hline Sep 1995-Sep 1996 & $\begin{array}{c}7.1 \pm 8.4 \\
4.0\end{array}$ & $\begin{array}{c}13.1 \pm 14.8 \\
7.2\end{array}$ & 10 & $\begin{array}{c}18.6 \pm 13.4 \\
17.7\end{array}$ & $\begin{array}{c}27.6 \pm 19.7 \\
27.9\end{array}$ & 13 & & \\
\hline Oct 1996-Dec 1997 & $\begin{array}{c}13.1 \pm 22.4 \\
18.7\end{array}$ & $\begin{array}{l}27.9 \pm 37.6 \\
25.9\end{array}$ & 4 & $\begin{array}{l}24.1 \pm 20.4 \\
21.8\end{array}$ & $\begin{array}{l}37.6 \pm 30.7 \\
39.6\end{array}$ & 15 & & \\
\hline
\end{tabular}


Similar to the phytoplankton biomass, the highest chlorophyll $a$ concentrations were found during the 1980 period $(200 \mathrm{mg}$ chlorophyll $a \mathrm{~m}^{-2}$ ), but the mean chlorophyll $a$ concentrations were highest during the early 1990 period (Table 6, Fig. 5). Significant differences were found between most of the years and periods (Tables 3 and 5), but there was no clear temporal trend detected.

PP rates exist only for the 1970 until the early 1990 periods. The late 1970 period data were with $33.9 \mathrm{mg} \mathrm{C} \mathrm{m}^{-2} \mathrm{~h}^{-1}$ about three to sevenfold lower than the other periods (Fig. 4 and 5, Table 6). It is not clear why the 1970 period values were so low. Unfortunately the original ${ }^{14} \mathrm{C}$ measurement protocols were not available, so the PP rates could not be verified. The primary production rates of the 1970 period were significantly different from all the other periods and years (Tables 3 and 5). Additionally, also significant differences were found between 1987-1988 and 1990-1991 (Table 7), but these do not indicate a temporal trend, because only four measurements were available in 1987-1988.

\section{Method validation I: nutrients and total phos- phorus}

Phosphorus was analysed by two methods differing in their sensitivities and their detection limits. First, the stannous chloride method applied in 1978-1979 is less sensitive compared to the ascorbic method (APHA 1992). Second, the smaller cell type and the different spectrophotometer used during the late 1970 period did not allow the reliable determination of phosphorus below the 5-10 $\mu \mathrm{g}$ $\mathrm{L}^{-1}$ range. It is not fully clear why the phosphorus concentrations during the late 1970's were significantly higher than during the following periods (Fig. 2 and 3, Table 2). It is probably that this may have been caused by the above mentioned variation in methodology.

The most important problem concerning nutrient analyses refers to the quantification of nitrate. Due to a calculation error nitrate was overestimated by a factor ten during 1978-1988 (G. Agüero and $\mathrm{H}$. Campos personal communication). Thus, the nitrate concentrations reported by Campos et al. (1987) for the late 1970 period and the unpublished data of the 1980 period were corrected by the factor $0.1 \mathrm{x}$. This resulted in nitrate concentrations ranging between 0 to $10 \mu \mathrm{g} \mathrm{N} \mathrm{L}^{-1}$ instead of 10 to $100 \mu \mathrm{g} \mathrm{N} \mathrm{L} \mathrm{N}^{-1}$ as originally calculated (see Table 2, Fig. 2).

Beside the above mentioned problems, the storage procedures and the use of different plastic bottles for the water samples might have caused part of the remaining spreading of the data on nutrient and TP concentrations. As shown in Table 7 , both the freezing procedure and the use of different storage bottles resulted in remarkable changes of the nutrient concentrations, which in part were significant. In general, freezing caused significant increase of soluble reactive phosphorus $(135 \%)$ and total phosphorus (223\%) (see Table 7). Similarly, different storage bottles influenced the nitrogen and phosphorus measurements with widely

TABLE 7

Influence of different treatments on the determination of nitrate, SRP and TP in lakewater from Lake Riñihue. All values (mean $\pm \mathrm{SD}$, range) are given as percentage

Influencia de diferentes tratamientos para la determinación de nitrato, FSR y TP en agua del Lago Riñihue. Todos los valores (promedio \pm DE, rango) son dados como porcentaje

\begin{tabular}{|c|c|c|c|c|}
\hline Treatment & $\mathrm{n}$ & Nitrate & SRP & $\mathrm{TP}$ \\
\hline Sample storaged / & 10 & $195 \pm 168$ & $135 \pm 106$ & $223 \pm 107$ \\
\hline Sample immediately analysed & & $(30-500)$ & $(0-286)$ & $(67-361)$ \\
\hline $\begin{array}{l}\text { Difference between treatments } \\
\mathrm{P}>|\mathrm{T}|\end{array}$ & & $\begin{array}{c}\text { Non-significant } \\
0.71\end{array}$ & $\begin{array}{l}\text { Significant } \\
0.0448\end{array}$ & $\begin{array}{l}\text { Significant } \\
0.0094\end{array}$ \\
\hline Plastic bottle $1 /$ & 10 & $89 \pm 48$ & $125 \pm 205$ & $91 \pm 38$ \\
\hline Plastic bottle 2 & & $(26-168)$ & $(0-700)$ & $(33-173)$ \\
\hline Difference between treatments & & 0.4610 & 0.0871 & 0.0198 \\
\hline $\mathrm{P}>|\mathrm{T}|$ & & Non-significant & Non-significant & Significant \\
\hline
\end{tabular}


spread values between different types of bottles (see Table 7). Although these results were only significant for TP, they clearly show the problems involved in the use of different bottle types and nutrient concentrations.

Finally, the data sets (only nutrients and total phosphorus) were corrected for outliers and extreme values (Fig. 3). The highest frequency of outliers was detected during the early 1990's concerning SRP and TP, followed by SRP during 1996/97 and to a lower degree by SRP and TP during the 1980's. Nitrate showed only a few outliers, but a much higher variation during the early 1990's.

\section{Method validation II: phytoplankton biomass and chlorophyll a}

The data on phytoplankton from the late 1970 period (Campos et al. 1987) were erroneous, because of the incorrect determination of the species composition and the phytoplankton biomass during this period due to an individual error (Fig. 4). Therefore, this data set was excluded from further statistical analyses.

The analytical method for chlorophyll $a$ determination during the late 1970 period most probably caused the degradation of chlorophyll $a$, because filter storage over two to four days at $4{ }^{\circ} \mathrm{C}$ before pigments extraction, yielded underestimated chlorophyll $a$ concentrations (Lenz \& Fritsche 1980). A good indication for this phenomenon is shown in Table 8, i.e., the chlorophyll $a$ values were in the same range or often below the corresponding chlorophyll $b$ and chlorophyll $c$ values. Therefore, this data set was excluded from further analyses.

\section{Method validation III: primary production}

First, due to a calculation error the alkalinity was overestimated by the factor 1.6x during April 1984-January 1988. This resulted in an overestimation of the PP rates by the same factor.

Secondly, the DIC obviously was calculated incorrectly by equation (1) during 1978-March 1985. This yielded DIC concentrations in the range of $2,500-3,000 \mathrm{mg}$ DIC m$~^{-3}$ instead of

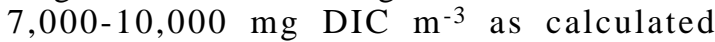
according to the (correct) equation (2). Consequently, the primary production rates per volume and per square meter were underestimated by $2.60 \mathrm{x} \pm 0.17(\mathrm{n}=190)$ and by $2.46 \pm 0.46(\mathrm{n}=31)$, respectively.

The correction of the primary production rates per square meter finally were done as follows: (A) 1978-March 1984: The DIC concentrations were calculated again using now equation (2) and afterwards the primary production rates; (B) April 1984-March 1985: the primary production rates were corrected for the wrong DIC concentrations as indicated above and additionally for the overestimated alkalinity. The final correction factor was 0.625 x $2.23=1.44$ x; (C) April 1985-January 1988: the primary production rates were corrected for the wrong alkalinity by the factor $0.625 \mathrm{x}$.

A review of the already published data base of the lakes Llanquihue, Puyehue, Ranco, Rupanco, Todos los Santos, and Villarrica (Campos et al. 1988, 1989, 1990, 1992a, 1992b) indicates that the primary production rates of these lakes also must be corrected. In the same way, the surprisingly high assimilation numbers during 1985-1986 reported by Montecino et al.

TABLE 8

Chlorophyll $a, b$ and $c$ in Lake Riñihue during two sampling days in 1978

(Campos et al. 1987, H. Campos unpublished results)

Clorofila $a, b$ y $c$ en el Lago Riñihue durante dos muestreos en 1978

(Campos et al. 1987, H. Campos resultados no publicados)

\begin{tabular}{|c|c|c|c|c|}
\hline Date & Depth & Chl $a\left(\mu \mathrm{g} \mathrm{L}^{-1}\right)$ & $\operatorname{Chl} b\left(\mu \mathrm{g} \mathrm{L}^{-1}\right)$ & Chl $c\left(\mu \mathrm{g} \mathrm{L}^{-1}\right)$ \\
\hline \multirow[t]{4}{*}{ 08/9/1978 } & 0 & 0.009 & 0.013 & 0.034 \\
\hline & 2 & 0.041 & 0.029 & 0.205 \\
\hline & 10 & 0.052 & 0.029 & 0.145 \\
\hline & 20 & 0.019 & 0.392 & 0.068 \\
\hline \multirow[t]{4}{*}{ 09/26/1978 } & 0 & 0.021 & 0.0094 & 0.0284 \\
\hline & 2 & 0.071 & 0.0589 & 0.1583 \\
\hline & 10 & 0.069 & 0.0836 & 0.0893 \\
\hline & 20 & 0.081 & 0.076 & 0.0138 \\
\hline
\end{tabular}


(1991) for Lake Riñihue are virtually caused by the overestimated primary production rates. After correction of the primary production rates the Riñihue data fit well in the range found for the other 14 Chilean and Argentine lakes.

Based on the anomalies reported here, we recommend to review very carefully the published data on trophic parameters (especially nitrate and primary production rates) of the north-Patagonian lake district by H. Campos and co-workers.

\section{Evidence for eutrophication processes?}

This study presents the most detailed data set on trophic parameters on a temporal scale of a single north Patagonian lake to date. Contrary to the expected results, only TP clearly indicated a continuous and significant temporal change with increasing values during the last two decades in lake Riñihue. None of the other parameters showed such a clear temporal trend: chlorophyll $a$ increased significantly during the early 1990 period, but declined during the mid 1990 period to values comparable to those of the 1980 period, whereas the phytoplankton biomass exhibited higher biomass during the 1980 period. These results agree well with those of Soto (2002) who found no clear temporal change of chlorophyll $a$ or phytoplankton in the 8-year study of four North Patagonian lakes (Llanquihue, Ranco, Puyehue, Rupanco). Soto (2002) however, considered only two sampling dates per year, a number which seems too low to detect significant long term changes.

There is no significant indication of eutrophication processes in Lake Riñihue as nor chlorophyll $a$ and PP neither SDT showed a significant response to the observed increase of TP. Also, there is no significant relationship between any parameter combined in a regression analysis, with exception of chlorophyll $a$ and PP which showed a week relationship PP $\left(\mathrm{mg} \mathrm{C} \mathrm{m}^{-}\right.$ $\left.{ }^{3} \mathrm{~h}^{-1}\right)=1.4275 \times \mathrm{Chl} \mathrm{a}{ }^{0.4813}\left(\mathrm{mg} \mathrm{m}^{-3}\right)\left(\mathrm{R}^{2}=0.46\right)$. In the literature, there is some evidence, that in Chilean and Argentinian lakes chlorophyll $a$ increases with TP and dissolved inorganic nitrogen (only Chilean lakes) (Quirós 1988, Díaz et al. 2000, Soto 2002). Soto (2002) reported for the Chilean lakes Llanquihue, Rupanco, Ranco y Puyehue a better predictive power of dissolved inorganic nitrogen than of TP. Díaz et al. (2000) argue that the prediction of chlorophyll a based on TP seems to be inappropriate for Chilean and Argentinian lakes. At least for lake Riñihue, this opinion is confirmed by our results. The lack of a positive relationship between phosphorus and chlorophyll $a$ might indicate that nitrogen limits more the phytoplankton growth than phosphorus. During a one-year study in Lake Riñihue, Figueroa (1998) found that phosphorus limitation is common year around, whereas nitrogen or nitrogen + phosphorus limitation is more likely during the summer.

We suggest that the increased concentration of TP over time in the lake is related to the change of the land use within the catchment area of lake Riñihue, where the transformation of the native vegetation may cause erosive processes resulting in higher nitrogen and/or phosphorus export to the lake basin (Soto \& Campos 1995, Soto \& Stockner 1996, Oyarzún et al. 1997).

H. Campos reported (unpublished results) two watershed areas in the Lake Riñihue basin had $3.5 \mathrm{x}$ and $10 \mathrm{x}$ the total phosphorus and nitrate export from grasslands when compared with exports of these nutrients from native forest lands, although no differences in SRP export were observed. Similar results were reported by Oyarzún et al. (1997) for six watershed areas in the Lake Rupanco region. The present data may reflect changes over time towards more grassland use within the catchment area of Lake Riñihue.

The fact that nitrate only showed an upward trend during the 1970-1990's, does not necessarily contradict this observation. It might be that in the case of a N-limitation algae take up rapidly nitrate resulting in low nitrate concentrations in the lakewater. To prove this, a more detailed analyses of the nutrient input and their fate in Lake Riñihue is necessary.

\section{ACKNOWLEDGEMENTS}

The database of this study was largely obtained by Dr. Hugo Campos, who died in 1998 during fieldwork. This publication is dedicated to the memory of him and his pioneer research and contribution to Chilean limnology. This study was financed by funding from the Dirección de Investigación y Desarrollo, Universidad Austral de Chile, DID 1999-50S and DID 2001-03. We thank Vivian Montecino and two anonymous referee for constructive comments. For technical assistance we thank Rosa Cárcamo.

\section{LITERATURE CITED}

APHA-AMERICAN PUBLIC HEALTH ASSOCIATION (1992) Standard methods for the examination of water and wastewater. Eighteenth edition. American Public Health Association, Washington, District of Columbia, USA. 983 pp. 
CAMPOS H , J ARENAS, W STEFFEN \& G AGÜERO (1978) Physical and chemical limnology of Lake Riñihue. Archiv für Hydrobiologie 84: 405-429.

CAMPOS H, W STEFFEN, C ROMÁN, L ZÚÑIGA \& G AGÜERO (1983) Limnological studies in Lake Villarrica: morphometric, physical, chemical, planktonical factors and primary productivity. Archiv für Hydrobiologie Supplement Band 4: 371-406.

CAMPOS H (1984) Limnological study of Araucanian lakes (Chile). Verhandlungen Internationale Vereinigung für Limnologie 22: 1319-1327.

CAMPOS H, W STEFFEN, G AGÜERO, O PARRA \& L ZÚÑIGA (1987) Limnology of Lake Riñihue. Limnologica (Berlin) 18: 339-357.

CAMPOS H, W STEFFEN, G AGÜERO, O PARRA \& L ZÚÑIGA (1988) Limnological studies of lake Llanquihue (Chile). Archiv für Hydrobiologie Supplement Band 81: 37-67.

CAMPOS H, W STEFFEN, G AGÜERO, O PARRA \& L ZÚÑIGA (1989) Estudios limnológicos en el Lago Puyehue (Chile): morfometría, factores físicos y químicos, plancton y productividad primaria. Medio Ambiente (Chile) 10: 36-53.

CAMPOS H, W STEFFEN, G AGÜERO, O PARRA \& L ZÚNIIGA (1990) Limnological study of Lake Todos Los Santos (Chile). Morphometry, physics, chemistry, plankton, and primary productivity. Archiv für Hydrobiologie 117: 453-484.

CAMPOS H, W STEFFEN, G AGÜERO, O PARRA \& L ZÚÑIGA (1992a) Limnological studies of Lake Rupanco (Chile). Morphometry, physics, chemistry, plankton and primary productivity. Archiv für Hydrobiologie Supplement Band 90: 85-113.

CAMPOS H, W STEFFEN, G AGÜERO, O PARRA \& L ZÚÑIGA (1992b) Limnology of Lake Ranco (Chile). Limnologica (Berlin) 22: 337-353.

CAMPOS H, A HUBER, O PARRA, L VILLALOBOS, E JAQUE, C OYARZÚN, C BERTRÁN, A BRAVO, M GRANDJEAN, D AVILÉS, G AGÜERO \& C CAMPUS (1998) Determinación de la capacidad de carga y balance de fósforo y nitrógeno del Lago Riñihue. Informe Final Proyecto FIP 96-53, Subsecretaría de Pesca, Ministerio de Economía y Universidad Austral de Chile, Valdivia, Chile. 280 pp.

CAMPOS H, D P HAMILTON, L VILLALOBOS, J IMBERGER \& A JAVAM (2001) A modelling assessment of potential for eutrophication of Lake Riñihue, Chile. Archiv für Hydrobiologie 151: 101-125.

DÍAZ M, F PEDROZO \& P TEMPORETTI (1998) Phytoplankton of two Araucanian lakes of differing trophic status (Argentina). Hydrobiologia 369-370: 45-57.

DÍAZ M, F PEDROZO \& N BACCALA (2000) Summer classification of southern hemisphere temperate lakes (Patagonia, Argentina). Lake and Reservoir Management 5: 213-222.

DONOSO TG \& H K PHINNEY (1987) Physical and chemical characteristics of Lake Rupanco, Osorno, Chile. Archiv für Hydrobiologie 112: 351-369.

DOKULIL M (1984) Metodología de medición de fotosíntesis en fitoplancton. Embalses, fotosíntesis y productividad primaria. In: Bahamonde N \& S Cabrera (eds) Programa sobre el hombre y la biosfera: 7384. UNESCO, Alfabeta, Santiago, Chile.

FIGUEROA J (1998) Nutrientes limitantes de la productividad fitoplanctónica en el Lago Riñihue (Región de Los Lagos-Chile). Master Thesis, Universidad Austral de Chile, Valdivia, Chile. 87 pp.

GELLER W (1992) The temperature stratification and related characteristics of Chilean lakes in midsummer. Aquatic Sciences 54: 37-57.

HAMILTON D P \& S G SCHLADOW (1997) Prediction of water quality in lakes and reservoirs: part I: model description. Ecological Modelling 96: 91-110.

IMBERGER J \& J C PATTERSON (1981) A dynamic reservoir simulation model - DYRESM5. - In: Fisher HB (ed) Transport models for inland and coastal waters: 310-316. Academic Press, New York, New York, USA

LENZ J \& P FRITSCHE (1980) The estimation of chlorophyll a in water samples: a comparative study on retention in a glass-fibre and membrane filter and on the reliability of two storage methods. Archiv für Hydrobiologie. Beihefte Ergebnisse der Limnologie 14: 46-51.

LÖFFLER H (1960) Limnologische Untersuchungen an chilenischen und peruanischen Binnengewässer. 1. Die physikalisch-chemischen Verhältnisse. Arkiv for Geofysik 3: 155-254.

MONTECINO V (1991) Primary productivity in South American temperate lakes and reservoirs. Revista Chilena de Historia Natural 64: 555-567.

OECD (1982) Eutrophication of waters. Monitoring assessment and control. Organisation for Economic Co-operation and Development, Paris, France. 154 pp.

OYARZÚN C, H CAMPOS \& A HUBER (1997) Exportacion de nutrientes en microcuencas con distinto uso del suelo en el sur de Chile (Lago Rupanco, X Región). Revista Chilena de Historia Natural 70: 507-519.

PEDROZO F, S CHILLRUD, P TEMPORETTI \& M DÍAZ (1993) Chemical composition and nutrient limitation in rivers and lakes of north Patagonian Andes 39.5-42 $\left.{ }^{\circ} \mathrm{S}, 71^{\circ} \mathrm{W}\right)$ (Rep. Argentina). Verhandlungen InternationaleVereinigung für Limnologie 25: 207-214.

QUIRÓS R (1988) Relationships between air temperature, depth, nutrients and chlorophyll in 103 Argentinan Lakes. Verhandlungen InternationaleVereinigung für Limnologie 23: 647-658.

SCOR-UNESCO (1969) Determination of photosynthetic pigments in sea water. Second edition. UNESCO, Imprimerie Rolland, Paris, France. 69 pp.

SOTO D (2002) Oligotrophic patterns in southern Chilean lakes: the relevance of nutrients and mixing depth. Revista Chilena Historia Natural 75: 377-393.

SOTO D \& H CAMPOS (1995) Los lagos oligotróficos del bosque templado húmedo del sur de Chile (Oligotrophic lakes in the temperate rain forest of southern Chile). In: Armesto JJ, MK Arrollo \& C Villagrán (eds) Ecología de los bosques nativos de Chile: 317-333. Editorial Universitaria, Santiago, Chile.

SOTO D \& JG STOCKNER (1996) The temperate rainforest lakes of Chile and Canada: Comparative ecology and sensitivity to anthropocentric change. In: Lawford R, P Alaback \& E Fuentes (eds) High latitude rain forest of the west coast of the Americas: climate, hydrology, ecology and conservation: 266280. Springer, New York, New York, USA

VILA I, M CONTRERAS, V MONTECINO, V PIZARRO J \& DD ADAMS (2000) Rapel: a 30 years temperate reservoir: eutrophication or contaminacion? Archiv für Hydrobiologie 55: 31-44.

WOELFL S (1995) Untersuchugen zur Zooplanktonstruktur einschliesslich der mikrobiellen Gruppen unter besonderer Berücksichtigung der mixotrophen Ciliaten in zwei süd-chilenischen Andenfusseen. Ph.D. Thesis, Faculty for Biology, University of Constance, Germany, Hartung Gorre Verlag Konstanz, Germany. 242 pp. ISBN 3-89191-995-6

ZHOU Q, CE GIBSON \& RH FOY (2000) Long-term changes of nitrogen and phosphorus loadings to a large lake in north-west Ireland. Water Research 34: $922-926$. 